\title{
Managerial skills go-green
}

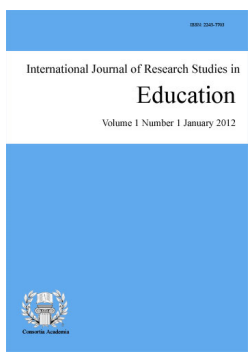

\section{Abstract}

This ex-post-facto study was aimed at investigating the influence of the Primary School principals' Go-green managerial skills and teacher's participation on students' environmental awareness. It employs a $3 \times 2$ factorial design with pencil-and-paper survey technique as the means of data collection. Two stage sampling technique has been implemented in selecting 590 respondents for the study that consist of 72 Primary School principals, 216 teachers, and 302 students. Findings of the study show that (1) Primary School principals' Go-green managerial skills significantly affect students' environmental awareness with $\mathrm{F}=172.37$; (2) Teachers' participation in implementing Go-green program significantly affect students' environmental awareness with $F=10.88$; however, (3) Interactional between school principals' Go-green managerial skills and teachers' participation in implementing Go-green program does not significantly affect students' environmental awareness with $\mathrm{F}=0.413$.

Keywords: managerial skills go green; participation; environmental awareness 


\section{Managerial skills go-green}

\section{Introduction}

In April 1968, the Club of Rome initiated the first concern on environmental issues. It suggests that the world is experiencing a crisis in five areas, i.e. natural resources, population, agriculture, industry and pollution (Meadows, 1972). Later in May 1968, the United Nations (UN) held a summit on population. In 1994, another Population summit was held in Cairo. The UN held an Environment summit in Stockholm in 1972, and Earth Summit held in Rio de Jenero in 1992. Therefore, the environmental problem is not the responsibility of individual countries or any particular entity but the whole world.

In response to the World Earth Summit, Indonesia has launched its 21st national agenda that includes:

$>$ Community services: (1) Elimination of poverty; (2) Change of consumption patterns; (3) The dynamics; (4) Health management and improvement; (5) Development of housing and settlement; (6) Integrated economic and environmental instruments.

$>$ Waste management: (7) Protection of the atmosphere; (8) Management of toxic wastes; (9) Management of toxic chemicals; (10) Management of radioactive wastes; (11) The management of solid and liquid wastes.

$>\quad$ Land Resources Management: (12) Restructuring of land resources; (13) Forest management; (14) Agriculture; (15) Rural development; (16) Management of water resources.

$>\quad$ Natural Resources Management: (17) Conservation of bio diversity; (18) Development; (19) the Integrated management of coastal and marine areas.

The policy was followed by the issuance of Law No. 32 of 2009 on the environment (Republic of Indonesia, 2009), stipulating that the environment is environment is unity of space with all things, power, states, and living things, including humans and their behavior, which affects the continuity of livelihood and well-being of humans and other living creatures. Environmental issues are also the main program of the United Nations Development Programme (UNDP), i.e. the Millennium Development Goals for 2015, particularly the Ensure Environmental Sustainability program. The realization of environmental awareness programs is conducted in the community at large with more strategic ones in the education community. The program was initiated with a student mentoring program that was developed based on the National Education Minister Decree number 39 of 2008 on Student Development (National Education Minister, 2009).

The purpose of student development is to: (a) optimum and integrated development of student potentials that includes their talents, interests, and creativity; (b) Build strong character in students to achieve school robustness as an educational environment so that it is resistance to any efforts and effects against educational purposes and goals; (c) actualize the potential of students for achieving excellence with regards to their respective talents and interests; (d) prepare students to become noble and democratic citizens who are respectful of the human rights so that a civil society can be achieved.

Student development is the school principal's responsibility. Indeed, it is a shared responsibility of the school management team, i.e. teachers and other staff. Fostering environmental awareness in students includes the development of democracy, human rights, political education, environment, social sensitivity and tolerance in a plural society. The school principal should drive the school community to establishing a Go-green school; that is, a school community that applies the environmental preservation and protection concept, particularly in the school and its surrounding areas. 
The Go-green program aims at establishing order, security and safety, cleanliness, beauty and familial atmosphere (Indonesian term: 5K). For successful achievement of the program, school principals, as managers school managers, need to possess the required managerial skills that include conceptual, technical, and human skills. They need to involve members of their respective school community - in this case, the teachers- in the implementation of this Go-green program.

\section{Theoretical Framework}

Go-green (5K) managerial skills are required of Primary School principals; i.e. technical skills, interpersonal skills, and conceptual skills related to effective and efficient structuring of all educational components that is supported by operating management functions. The implementation of Go-green program also requires the school principal skills in planning, managing and supervising the program. A Go-green school will be a safe, orderly, clean, beautiful place with familial atmosphere. Such school environment will be potential in growing environmental awareness in students and promotes positive development of such awareness. Emor's study (1994) on students' environmental awareness finds positive correlation between students' environmental awareness and their perceptions of marine resource management $(r=0.78)$. The study of Suprihatin, Abdurrahman and Fadjarajani (2014) identifies strong relationship between school principal's management role and teachers' participation in managing environment cleanliness and student behavior in maintaining environment cleanliness at a co-eficient of 0.632 with $40 \%$ contribution share. A study by Kustiani, Priyadi dan Ratnaningsih (2014) on relationship between the implementation of green school program and teachers' participation in the program and students' behavior in maintaining gardens in school area also identifies strong relationship with $27.1 \%$ contribution share.

The influence of Teachers' participation in implementing the Go-green program (5K) to students' environmental awareness. Teachers' participation refers to their physical, mental, emotional and sense of responsibility involvement in Go-green program management. Since teachers play the major role in school activities, most part of school programs are conducted by them, both inside and outside of the classrooms. Teachers' involvement in implementing Go-green program occurs in their teaching-learning activities in the classroom and when they direct and supervise school activities outside the classrooms. All activities are directed to support the Go-green program implementation that aims at building a habit to live an orderly, safe, clean, and beautiful life as well as to make their surrounding environment part of their life. Creating such conditions is an effort to promote development of students' environmental awareness. As a whole, the concept is illustrated in the following research framework.

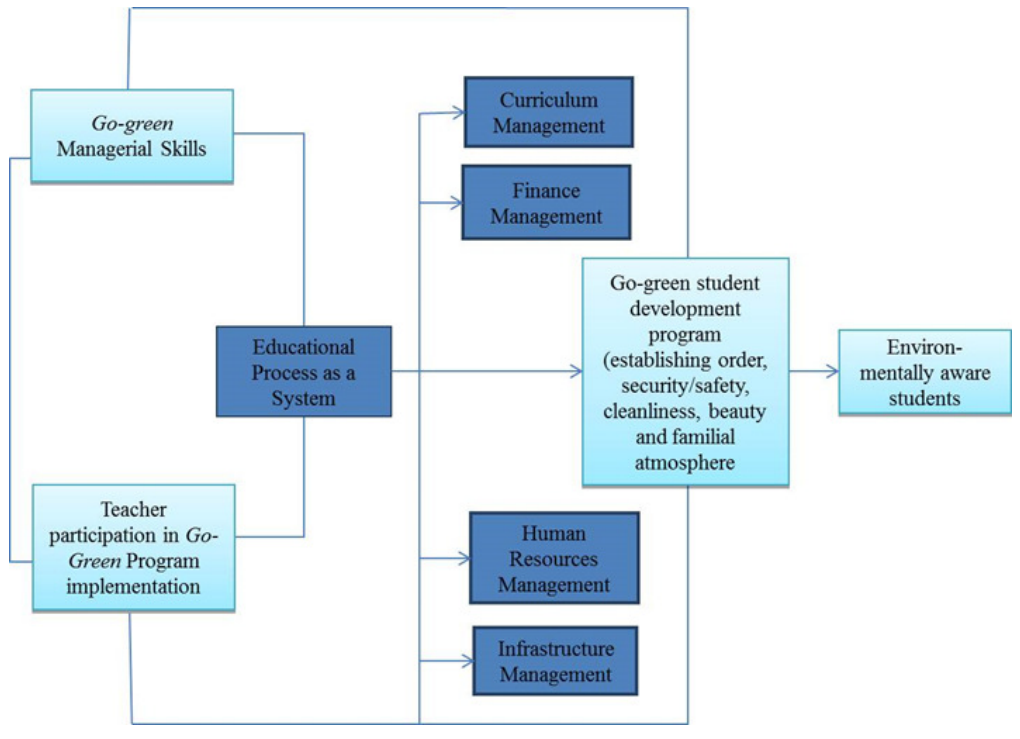

Figure 1. Research Framework 


\section{The Study}

This study employs an ex-post-facto approach; i.e. an empirical and systematic study in which scientists do not directly control the independent variables, because the variable embodiment has occurred (Ary, Jacob, \& Razavieh, 1979). It employs a 3x2 factorial design which is illustrated in Figure 2.

\begin{tabular}{cccc}
\hline & \multicolumn{3}{c}{ 5K Managerial skills of Primary School Principals (A) } \\
\hline \multirow{2}{*}{ Teachers' participation (B) } & Low & Medium & High \\
& (A1) & (A2) & (A3) \\
Inactive (B1) & Y1 & Y2 & Y3 \\
Very active (B2) & Y4 & Y5 & Y6 \\
\hline
\end{tabular}

Figure 2. Research design model

\subsection{The survey}

Paper-and-pencil survey has been employed in this study in which respondents provide their responses to a Likert-type questionnaire. The survey measures Go-green managerial skills of respondents who consist of school principals and teachers participating in Go-green program. In addition, students were involved to measure their environmental awareness. The survey on Go-green managerial skills measures conceptual, interpersonal and technical skills dimensions of the school principals in their planning, managing and supervising the program. Managerial capacity was measured by means of a set of Likert questionnaire that focuses on measuring very positive and less positive responses. Survey on Teachers' participation in the program measures the mental, emotional, contribution and responsibility of participating teachers in implementing the program. Teachers' participation was measured by means of a set of Likert questionnaire that aimed at very observable (very active) to non observable (inactive) responses. Survey on studen environmental awareness measures the suitability of individual responses in their interactions with their surrounding physical, social and biological environment and how they make their environment as part of themselves. Student environmenal awareness was measured by means of a set of Likert questionnaire that aimed at very concerned to unconcerned responses.

\subsection{Analysis and limitation}

Despite optimum efforts made to obtain the best results, this study failed to avoid the occurence of many inadequacy and limitations. Firstly, there are limitations related to the methods of the study. The ex-post-facto method has posed the following limitations: (1) the researcher cannot do a direct treatment (treatment has occurred) to the variable, so it is difficult to determine whether variable $\mathrm{x}$ has really affected variable $\mathrm{y}$; (2) ex-post-facto method does not control the variables, so the differences are achieved not by manipulating but selecting individuals who have or do not have the variable. To minimize the limitations of the study, the researchers employed a two-stage sampling technique. The first phase was a multi-stage sampling in which sample areas for the study was determined by keeping in mind the representativeness of the region and its characteristics. Distribution of the selected region includes Jagakarsa, Pancoran, Kebayoran Baru, Tebet and Setiabudi sub-districts. These subdistricts are considered as well-representing the South Jakarta administrative area. Secondly, there are limitations in the data collection. The paper-and-pencil instruments used in the form of questionnaires returned with responses that tend to denote an "everything is $\mathrm{OK}$ " conditions. Observation technique in data collection can be employed to ensure greater reliability of responses. To ensure greater validity and reliability of obtained data of the study, validation and reliability tests were performed to the sets of questionnaire instruments prior to their use in the data collection process.

\subsection{The Participants}

590 respondents that consist of 72 school principals, 216 teachers, and 302 students have been involved in the study. School-principal and teacher respondents were selected based on their service time. $46.6 \%$ of the 
school principals have 21-30 years of service time and another 47.2\% have 31-40 years. Most (57.9\%) teacher respondents have between 11-20 years of service time. The rest $16.2 \%$ of teacher respondents have been teaching for 21-30 years and $22.7 \%$ with less than 10 years of service time. Students selected as respondents of the study were 5 th graders.

\section{Results and discussion}

Results of the study signify the average level of students' environmental awareness that is influenced by the level of Go-green managerial skills of the school principals as well as Teachers' participation in implementing the program. The findings are presented in the following table.

\section{Table 1}

Student environmental concern

\begin{tabular}{|c|c|c|c|c|}
\hline $\begin{array}{l}\text { 5K managerial skills of } \\
\text { Primary School principals (A) }\end{array}$ & \multirow{2}{*}{$\begin{array}{l}\text { 5K managerial } \\
\text { skills of Primary } \\
\text { School principals } \\
\text { Low } \\
\text { (A1) }\end{array}$} & \multirow{2}{*}{$\begin{array}{l}5 \mathrm{~K} \text { managerial } \\
\text { skills of Primary } \\
\text { School principals } \\
\text { Medium } \\
\text { (A2) }\end{array}$} & \multirow{2}{*}{$\begin{array}{l}5 \mathrm{~K} \text { managerial } \\
\text { skills of Primary } \\
\text { School principals } \\
\text { High } \\
\text { (A3) }\end{array}$} & \\
\hline $\begin{array}{l}\text { Teachers' participation in } \\
\text { implementing } 5 \mathrm{~K} \text { program (B) }\end{array}$ & & & & \\
\hline Non active (B1) & $\begin{array}{l}\mathrm{n}=58.00 \\
\mathrm{x}=75.17\end{array}$ & $\begin{array}{l}\mathrm{n}=49.00 \\
\mathrm{x}=80,96\end{array}$ & $\begin{array}{l}\mathrm{n}=52.00 \\
\mathrm{x}=86,50\end{array}$ & 80.66 \\
\hline $\begin{array}{l}\text { Highly active participation } \\
\text { (B2) }\end{array}$ & $\begin{array}{l}\mathrm{n}=53.00 \\
\mathrm{x}=76.51\end{array}$ & $\begin{array}{l}\mathrm{n}=52.00 \\
\mathrm{x}=83.25\end{array}$ & $\begin{array}{l}\mathrm{n}=38.00 \\
\mathrm{x}=87,82\end{array}$ & 81.97 \\
\hline & 75.81 & 82.14 & 87.06 & \\
\hline
\end{tabular}

It can be observed in Table 1 that, in average, the very high level of students' environmental awareness is an effect of the high level of Go-green managerial skills of the school principal. On the other hand, medium level students' environmental awareness is the effect of Teachers' participation, either active or inactive, in implementing the Go-green program. For your better understanding, the following sections describe findings of the study in more details.

Low level of students' environmental awareness is influenced by low level of Go-green managerial skills and non active participation of teachers (A1B1).

Table 2

Student environmental concern in group A1B1

\begin{tabular}{lrlr}
\hline Mean & 75.172 & S. E. Mean & .585 \\
Std Dev & 4.453 & Variance & 19.829 \\
Kurtosis & 2.080 & S.E. Kurt & .618 \\
Skewness & -1.199 & S.E. Skew & .314 \\
Range & 24.000 & Minimum & 60.00 \\
Maximum & 84.000 & Sum & $4,360.00$ \\
\hline
\end{tabular}

Table 3

Frequency distribution of group A1B1

\begin{tabular}{cccc}
\hline No & Score & Absolut frequency & Relative frequency (\%) \\
\hline $60-63$ & 1 & 1.7 \\
$64-67$ & 5 & 8.6 \\
$68-71$ & 1 & 1.7 \\
$72-75$ & 20 & 34.4 \\
$76-79$ & 24 & 41.6 \\
& $80-83$ & 6 & 10.3 \\
& $84-86$ & 1 & 1.7 \\
\hline & 58 & 100.0 \\
\hline
\end{tabular}

Note. Number of Valid Observation (Listwise) $=58.00$, Variabel Y (Kepedulian). 
Data in the above tables reveal that low level of Go-green managerial skills of the school principal and non active participation of teachers lead to low level of students' environmental awareness.

$>$ Medium level of students' environmental awareness is influenced by medium level of Go-green managerial skills and non active participation of teachers (A2B1).

\section{Table 4}

Student environmental concern in group A2B1

\begin{tabular}{lrlr}
\hline Mean & 80.959 & S. E. Mean & .747 \\
Std Dev & 5.232 & Variance & 27.373 \\
Kurtosis & .289 & S.E. Kurt & .668 \\
Skewness & .498 & S.E. Skew & .340 \\
Range & 26.000 & Minimum & 70.000 \\
Maximum & 49.000 & Sum & $3,967.000$ \\
\hline
\end{tabular}

Table 5

Frequency distribution of group A2B1

\begin{tabular}{cccc}
\hline No & Score & Absolut frequency & Relative frequency $(\%)$ \\
\hline $70-73$ & 2 & 4 \\
$74-77$ & 11 & 22.5 \\
$78-81$ & 16 & 32.6 \\
$82-85$ & 10 & 20.5 \\
$86-89$ & 7 & 14.2 \\
$90-93$ & 2 & 4.1 \\
$94-97$ & 1 & 2 \\
\hline & 49 & 100.0
\end{tabular}

Note. Number of Valid Observation (Listwise) $=49.00$, Variabel Y (Kepedulian).

Data in the above tables suggest that medium level of Go-green managerial skills of the school principal and non active participation of teachers result in medium level of students' environmental awareness.

High level of students' environmental awareness is influenced by high level of Go-green managerial skills and non active participation of teachers (A3B1)

\section{Table 6}

Student environmental concern in group A3B1

\begin{tabular}{lrlr}
\hline Mean & 86.500 & S. E. Mean & .680 \\
Std Dev & 4.901 & Variance & 24.020 \\
Kurtosis & -.422 & S.E. Kurt & .650 \\
Skewness & -.156 & S.E. Skew & .330 \\
Range & 20.000 & Minimum & 76.000 \\
Maximum & 52.000 & Sum & $4,498.000$ \\
\hline
\end{tabular}

Table 7

Frequency distribution of group A3B1

\begin{tabular}{cccc}
\hline No & Score & Absolut frequency & Relative frequency $(\%)$ \\
\hline $76-78$ & 3 & 5.8 \\
$79-81$ & 7 & 13.5 \\
$82-84$ & 7 & 13.5 \\
$85-87$ & 11 & 21.1 \\
$88-90$ & 17 & 32.6 \\
$91-93$ & 2 & 3.8 \\
$94-96$ & 5 & 9.6 \\
\hline & 52 & 100.0 \\
\hline
\end{tabular}

Note. Number of Valid Observation (Listwise) $=52.00$, Variabel Y (Kepedulian). 
Data in the above tables denotes that high level of Go-green managerial skills of the school principal and non active participation of teachers result in high level of students' environmental awareness.

$>\quad$ Low level of students' environmental awareness is influenced by low level of Go-green managerial skills and active participation of teachers (A1B2)

\section{Table 8}

Student environmental concern in group AlB2

\begin{tabular}{lrlr}
\hline Mean & 76.509 & S. E. Mean & .686 \\
Std Dev & 4.991 & Variance & 24.909 \\
Kurtosis & .406 & S.E. Kurt & .644 \\
Skewness & .306 & S.E. Skew & .327 \\
Range & 23.000 & Minimum & 65.000 \\
Maximum & 88.000 & Sum & $4,055.000$ \\
\hline
\end{tabular}

Table 9

Frequency distribution of group A1B2

\begin{tabular}{cccc}
\hline No & Score & Absolut frequency & Relative frequency $(\%)$ \\
\hline $76-78$ & 3 & 5.8 \\
$79-81$ & 7 & 13.5 \\
$82-84$ & 7 & 13.5 \\
$85-87$ & 11 & 21.1 \\
$88-90$ & 17 & 32.6 \\
$91-93$ & 2 & 3.8 \\
& $94-96$ & 5 & 9.6 \\
\hline & 52 & 100.0 \\
\hline
\end{tabular}

Note. Number of Valid Observation (Listwise) $=52.00$, Variabel Y (Kepedulian).

Data in the above tables reveal that low level of Go-green managerial skills of the school principal and very active participation of teachers result in low level of students' environmental awareness.

Medium level of students' environmental awareness is influenced by medium level of Go-green managerial skills and very active participation of teachers (A2B2)

\section{Table 10}

Student environmental concern in group $A 2 B 2$

\begin{tabular}{lrlr}
\hline Mean & 83.250 & S. E. Mean & .333 \\
Std Dev & 2.400 & Variance & 5.760 \\
Kurtosis & -.082 & S.E. Kurt & .650 \\
Skewness & .576 & S.E. Skew & .330 \\
Range & 10.000 & Minimum & 79.000 \\
Maximum & 52.000 & Sum & $4,329.000$ \\
\hline
\end{tabular}

\section{Table 11}

Frequency distribution of group A2B2

\begin{tabular}{cccc}
\hline No & Score & Absolut frequency & Relative frequency (\%) \\
\hline $76-78$ & 3 & 5.8 \\
& $79-81$ & 7 & 13.5 \\
$82-84$ & 7 & 13.5 \\
& $85-87$ & 11 & 21.1 \\
$88-90$ & 17 & 32.6 \\
& $21-93$ & 5 & 3.8 \\
& $94-96$ & 52 & 9.6 \\
\hline
\end{tabular}

Note. Number of Valid Observation (Listwise) $=52.00$, Variabel Y (Kepedulian). 
Data in the above tables suggest that medium level of Go-green managerial skills of the school principal and very active participation of teachers leads to medium level of students' environmental awareness.

$>\quad$ Low level of students' environmental awareness is influenced by high level of Go-green managerial skills and very active participation of teachers (A3B2)

\section{Table 12}

Student environmental concern in group A3B2

\begin{tabular}{lrlr}
\hline Mean & 87.816 & S. E. Mean & .462 \\
Std Dev & 2.846 & Variance & 8.100 \\
Kurtosis & 2.011 & S.E. Kurt & .750 \\
Skewness & -.776 & S.E. Skew & .383 \\
Range & 14,000 & Minimum & 80.000 \\
Maximum & 94.000 & Sum & $3,337.000$ \\
\hline
\end{tabular}

Table 13

Frequency distribution of group A3B2

\begin{tabular}{cccc}
\hline No & Score & Absolut frequency & Relative frequency (\%) \\
\hline $80-82$ & 3 & 7.8 \\
& $83-85$ & 20 & 5.2 \\
$86-88$ & 2 & 52.7 \\
$89-91$ & 11 & 29 \\
& 2 & 5.3 \\
\hline & 38 & 100
\end{tabular}

Note. Number of Valid Observation (Listwise) $=38.00$, Variabel Y (Kepedulian).

Data in the above tables suggest that high level of Go-green managerial skills of the school principal and very active participation of teachers leads to high level of students' environmental awareness. Findings of the study show that (1) Go-green managerial skills of Primary School principals significantly affect students' environmental awareness with $\mathrm{F}=172.37$; (2) Teachers' participation in implementing Go-green program significantly affect students' environmental awareness with $\mathrm{F}=10.88$; however, (3) Interactional between school principals' Go-green managerial skills and teachers' participation in implementing Go-green program does not significantly affect students' environmental awareness with $\mathrm{F}=0.413$.

School principals' Go-green managerial skills significantly affect students' environmental awareness. These results indicate that school principals' Go-green managerial skills cannot be ignored. Teachers' participation in implementing the Go-green program significantly affects students' environmental awareness. These results indicate that teachers' participation in implementing the Go-green program cannot be ignored. The interaction between Primary School principals' Go-green managerial skills and teachers' participation in implementing the Go-green program has not yet been supported empirically. Therefore, results of this study can be used as a source of scientific information in setting educational policy

\subsection{Implication}

Findings of the study indicate that school principals' Go-green managerial skills significantly affect students' environmental awareness. They signify a need for efforts towards improvement of school principals' Go-green managerial skills. Such efforts can be attempted trough pre-service as well as in-service education that is supported by formal education program, at least, at undergraduate or S1 level. It is recommended that very active participation of teachers be enhanced and supported by school principal's managerial skills and proper provision of rewards, both in terms of materials such as bonus income and non-materials such as certificate of achievement that contribute extra credits to teachers' career. Very active participation of teachers in implementing the managerial activities will eventually promote environmental awareness in students.

Furthermore, it is necessary to trust the school principal for managing the school for which she is 
responsible for establishing optimum learning condition and growing environmental awareness in students. In addition the Population and Environment Education program integrated in the curriculum as a school subject, efforts to raise awareness of the environment need to be accompanied by adequate availability of school facilities and infrastructure. With a view to creating clean and beautiful school, schools need to be completed with fence and gate, well-maintained gardens, clean restroom, and adequate coop store with a healthy canteen. Management of all these aspects requires sound managerial skills to ensure effective and efficient achievement of school goals. To maintain and enhance students' environmental awareness can be attempted through the Go-green contests in the form of cleanliness, beauty, or orderly contests at school level, or village, district, municipality; or even to the national level. Such efforts should not stop at the end of the contests, but be developed continuously, either by the school principal or superintendent.

\section{References}

Ary, D., Jacobs, L. C., \& Razavieh, A. (1972). Introduction to research in education. New York: Holt, Rinehart, and Winston.

Astalin, P. K. (2011). A study of environmental awareness among higher secondary students and some educational factors affecting it. International Journal of Multidisciplinary Research, 1(7), 90-101.

Brophy, J., \& Evertson, C. (1981). Student characteristics and teaching. New York: Longman.

Davis, K. (2005). Behavior in organizations [Perilaku dalam Organisasi]. Yogyakarta: Gajahmada Press.

Jurie, A. (1994). Knowledge of marine ecosystems, environmental concerns and perceptions of students about the management of marine resources [Pengetahuan tentang ekosistem kelautan, kepedulian lingkungan dan persepsi mahasiswa tentang pengelolaan sumber daya laut]. Unpublished Thesis. Jakarta: Universitas Negeri Jakarta.

Katz, R. (2009). Skills of an effective administrator (Harvard Business Review Classics). MA: Harvard Business School Press.

Koontz, H., O’donnell, C., \& Weihrich, H. (1990). Management. Tokyo: McGraw Hill.

Kustiani, P., \& Ratnaningsih. (2014). Green School. Jurnal Universitas Siliwangi Tasikmalaya, 3(1), 71-73.

Mannarswamy, S. (2011). A study of environmental awareness and the changing attitude of the students and the public in Coimbatore towards green products. Journal of Social Science and Management, 1, 5-84.

Meadows. (1994). The human environment [Lingkungan hidup manusia]. Jakarta: Pustaka Sinar Harapan.

Naga, D. S. (2002). Introduction to the theory of scores on educational measurement [Pengantar teori skor pada pengukuran pendidikan]. Jakarta: Gunadharma.

National Education Minister. (2008). Regulation No. 39 of 2008 on student development [Peraturan Menteri Pendidikan Nasional Nomor 39 Tahun 2008 tentang pembinaan kesiswaan]. Jakarta, Indonesia.

Popham, W. J. (1981). Modern educational measurement. Englewood Cliffs, NJ: Prentice-Hall.

Republic of Indonesia. (2009). Law No. 32 of 2009 on the Protection and Management of the Environment. Additional State Gazette, 5059. Indonesia.

Simha, B. (2013). A study of environmental awareness and ecological behavior among female and B.Ed. student. Educational Perspectives, 2(1), 42-50.

Singh, S. K. (2008). Human resource development. New Delhi: Atlantic.

Suprihatin, A., \& Fadjarajani. (2014). The relationship between the principal's role as manager and teachers' participation in environmental hygiene with student behavior in maintaining school environment cleanliness [Hubungan antara peranan kepala sekolah sebagai manajer dan partisipasi guru da]. Jurnal Universitas Siliwangi Tasikmalaya, 3(1), 1-12. 
